PROBLEMS

OF MANAGEMENT IN THE $21^{\text {st }}$ CENTURY Vol. 12, No. 2, 2017

\title{
RISK MANAGEMENT AND RISK COMMUNICATION IN MOZAMBIQUE: THE CASE OF ARMS AND AMMUNITION DEPOTS OF MALHAZINE
}

\author{
Luca Bussotti \\ International Studies Centre of ISCTE-IUL, Portugal \\ Technical University of Mozambique, Mozambique \\ E-mail: Luca.Bussotti@iscte-iul.pt
}

\begin{abstract}
Risk management and risk communication affect everybody's daily life. Local authorities have the duty to manage public structures, to inform civilians of the risks coming from these structures, to implement prophylaxis procedures. Military storage sites are fully included in this category. This article presents through a qualitative methodology based on risk analysis - how risk management and communication in weapons and ammunition warehouses is managed in a "partially free" country, using as a case-study, the Malhazine depot in Mozambique, which resulted in more than 100 deaths. In 2007, an extraordinary accident related to the management of obsolete conventional weapons occurred at the Malazhine warehouse. In this circumstance, the Mozambican Government adopted a policy of classifying the information "highly confidential". This policy aimed at obscuring facts and responsibilities by hiding the causes of such a huge tragedy. This article concludes with the consideration that a high level of confidentiality in treating issues of public interest, such as the one kept in regard to Malhazine, does not help public authorities to effectively manage and prevent similar risks from occurring again, with resulting negative impacts on local populations.
\end{abstract}

Keywords: military storage, Malhazine, local authorities, confidentiality.

\section{Introduction}

Among the man-made risks, the risk originating by explosions of a weapon or ammunition at their storage sites is one of the less understood and, therefore, one of the most dangerous.

The frequency of these accidents, in particular after the 1990s, has increased. Their impact was terrifying due to high demographic density near many of these sites. In fact, from 1995 to 2010218 accidents of this kind were registered, which caused 4.700 fatalities and about 5.700 people suffering injuries (U.S. Department of State, 2010).

The areas in which such events were more frequent are Eastern Europe and Africa and, secondly, Latin America. In Eastern Europe, the most devastating incidents were the ones occurring in Serbia (and Afghanistan) in 2006, Gërdec (Albania), Bulgaria and Uzbekistan in 2008, Ulyanovsk (Russia) and in Kazakhstan in 2009. In Africa, tremendous accidents occurred in Nigeria in 2002, resulting in more than 1000 deaths, in the Congo Democratic Republic (300 deaths) in 2009, Sudan in 2007, Mozambique in Beira in 2003 and in Maputo (Malhazine) in 2005 and 2007, Tanzania in 2011 (26 deaths). Finally, the most serious accident of this kind in Latin America occurred in 1995 in Brazil, where an explosion at an ammunition warehouse took more than 100 lives (U.S. Department of State, 2010).

In order to decrease this risk, in 1993, the U.S. Department of State, funded a campaign of about 2 billion dollars in nearly 50 countries. A great part of the money was used to discard obsolete weapons. Nevertheless, these measures proved to be insufficient to eliminate explosions and the consequent damages without accountability measures, which "will continue to become 
more important" than the intervention of international community (Rutherford \& Williams, 2015: 56).

The risk represented by such a great concentration of weapons and ammunition in military storage units faces an evident contradiction between the management of these depots and the principles of risk communication. This research aims at analysing how arms depots are managed in one of these countries characterized by a limited level of democracy, Mozambique. The main hypothesis is that specific reasons - namely the continuous political-military tension - have induced the local government to adopt a "silence strategy" regarding the management of the risk herein considered; and that this option has resulted in fatalities and in the impossibility to improve the security of ammunition storages all over the country, as clearly demonstrated by the fact that, after Malhazine's explosion, other similar incidents occurred in Mozambique.

This research is embedded into the theory of risk management and risk communication, using as its main framework political risk analysis (Bussotti, 2014; Bussotti, 2015). This approach employs a qualitative methodology, based Mozambique as case study. In addition to international documents, a limited number of local documents and comments in newspapers or in blogs available are analysed as well. An attempt to incorporate some oral sources was been carried out, but their level of confidentiality was so high that this material could not be used for a scientific article.

\section{Theoretical Framework: Risk Management and Risk Communication}

"Risk" has assumed a pivotal importance in current social sciences, taking on with time various formulations and interpretations. If its origins, in modern age, can be found in the financial calculation of risk by Italian merchants starting from the $15^{\text {th }}$ century, this process brought, in the age of capitalism, to more and more sophisticated risk calculation (Purcell, 2016). Following a Weberian tradition, many authors stated that a "rational state," with professional bureaucracy, where there is certainty of administrative procedures, and without corruption (e.g. nepotism and conflict of interests by public servants), is necessary to allow the entrepreneur to focus his/her attention on assessing the risk stemming from economic factors (Dahl, 1957; Kalberg, 1980).

In these first conceptualizations of risk the economic and financial perspectives prevailed. It was only in the United States, with the "Chicago School", that other forms of risk, namely linked to environmental issues, began to be included in sociological studies, pointing out the necessity to join urban planning with social interventions.

Nevertheless, specific events after the end of the Second World War served to catalyse the attention of public opinion regarding environmental and man-made risks. Very serious accidents of great industrial plants all over the world helped to develop a different concept of risk and risk communication: only to remember some of them, it is worth here mentioning the Little Rock AFB (Arkansas) accident in 1965, which killed 65 workers, the Seveso disaster in Italy in 1976, in which a very dangerous toxic cloud of dioxin released from the plant of ICMESA of Meda, the Three Miles Island nuclear explosion in 1979, the Chernobyl disaster in 1986 caused by a problem at the nuclear power plant in Prypiat (Ukraine), the Bhopal disaster in India in 1984, in which the Union Carbide Pesticide Plant began to leak toxic gases into the atmosphere, with about 15.000 deaths, the collision of the Exxon Valdez with the Bligh Reef in 1989, which created an oil spill which killed about a quarter million birds, the Fukuyama nuclear disaster in 2011, only to name a few.

It was during the sixties that a new approach towards man-made risks was formulated, starting from the analysis of nuclear and technological risks (Sowby, 1965; Starr, 1969). Such concepts were understood outside the academic circles thanks to the formulations of sociologists such as Luhmann, Beck, Giddens and Douglas (Luhmann, 1979; Beck, 1986; Giddens, 1990; Douglas, 1992). These authors consider risk as the main component of a "second modernity" or "reflexive modernity" (Beck, Giddens \& Lash, 1994), whose main feature is the unpredictability of this kind of risks (Lupton, 1999; Sousa Santos, 2004). 
PROBLEMS

OF MANAGEMENT

IN THE $21^{\text {st }}$ CENTURY

Vol. 12, No. 2, 2017

Building on the analyses of the authors above mentioned and from studies on risk perception (Slovic, 1993; Sjöberg, Moen \& Rundmo, 2004), a consistent group of scholars developed the idea that risk can be better managed through planned strategies of risk communication. In short, risk communication is the comprehension of both scientific and technological risks within a certain structure, which cannot neglect to transmit to the public this knowledge in a very simple way. It also, includes, a political strategy to openly communicate the possible consequences of this risk (Sinisi, 2004; Covello, 1983; Slovic, 1987), developing best practices to prevent, face and manage risk.

In the nineties specific strategies of communication were conceived in order to face situations of "crisis" (Fiorino, 1990; Covello, Sandman \& Slovic, 1998; Sandman, 2001).

Awareness regarding these issues has been growing quickly in the last thirty years in Western countries, also thanks to the role of mass-media which, in many cases, have adopted, as their editorial lines, the social amplification of risk (Kasperson et al., 1988).

The scenario in countries with limited levels of democracy - as the great part of the countries involved in explosions of weapons warehouses - and even more in a military context is completely different: institutional accountability is modest if not null. Thus, the management of these structures is left to be handled by economic, politic and military elites who often have personal interests in hiding the nature of their activities. Therefore, risk communication rarely is applied, maintaining a high level of discretion.

\section{Risk Management and Risk Communication in Ammunition Depots}

The risk deriving from ammunition depots and especially the explosions of arms within them can be included in the vast category of the man-made risks. Its management has to respect some basic principles which constitute a guarantee to reduce the risk of tragic events. Military bodies should share with public opinion, especially local authorities and people living nearby the arms depot, the essential information regarding the management of these warehouses and the measures to reduce risks. Such approach has been defined as "stockpile management": it designates "a wide-ranging term that covers specific technical areas related to the safety and security of ammunition and explosives in accounting, storage, transportation and handling" (SAFERWORLD, 2012: 3). Today, of the about 200 million military firearms, 76 million are surplus. As pointed out by the Safeworld report, "lax security makes theft easy", with the decisive help of corrupted officials, increasing considerably the risk of disasters, first of all explosions (IDEM: 3).

As in the case of great plants, the concept of risk management in stockpiles includes the principles of good practices, accountability and information to local communities.

At least four main international documents regulate the way in which conventional ammunition should be registered and stored: 1) U. N. Resolution 60/74 2) U.N. Programme of Action to Prevent, Combat and Eradicate the Illicit Trade in Small Arms and Light Weapons in All Its Aspects (approved in 2001), according to which each State should implement a legal system to establish adequate and detailed procedures to manage stockpiles; 3) the Document produced by OSCE on the conventional ammunition stock, FSC.DOC, November, the $19^{\text {th }} 2013$, and 3) the Document STANAG 2953 regarding the identification of ammunition (AOP-3(B).

Three basic practices are recommended: ammunition markings, registration and register keeping (OSCE, 2008). Each practice aims at limiting a specific risk; the "ammunition markings" practice - which means to have complete information regarding characteristics of the ammunition, which span from the make to the date of production - aims at reducing the risk stemming from the "manipulation" of specific weapons. For instance, ammunition containing explosives or other dangerous substances (such as phosphor) need to be classified according to their hazard level. Ammunition markings are also a useful tool in tracking down the source of ammunitions during criminal investigations, such ownership and use of illicitly acquired ammunition. 
All ammunition (including the obsolete ones), awaiting for destruction, should be registered carefully. Each piece of ammunition should be identified, in order to know its legal status and where it is stored. Register keeping deals with the registration of data collected through registration; together with registration, register keeping should accompany an ammunition for its entire "life", from production to destruction (IDEM).

In addition to the ammunition marking and registration, the storage of conventional ammunition entails a set of activities directed to reduce the risk of explosion or other serious accidents. Inventory should be updated monthly or quarterly and each peripheral location should inform the main centre, if possible, through an electronic system managed online. This activity aims at knowing if, during the relevant period, some material was lost, due to theft, accident, etc. At the end of each year, in order to verify the effective stocks of ammunition, a physical inventory (i.e., a manual counting) should be produced.

Internal reports are very important so that an effective information updating about ammunition stocks can be performed. Within 72 hours every kind of loss, including theft or destruction of ammunition and explosives, should be communicated to the central command. This, above-mentioned practice should be implemented to facilitate the recovering of any lost material. All these activities make necessary to carry out a process of specific professional development for employees, so that at the macro level there is an effective knowledge, at any given time, of the stockpile of ammunition and explosives.

Risk management in military commands is not limited to the ammunition markings, registration and record keeping of each single piece; it is very important to avoid a mixed storage: in fact, due to the chemical properties of a substantial fraction of ammunition and explosives, mixed storage can increase the risk of an explosion and compound its consequences. The top priority in regard to the management of an ammunition storage site is protecting the environment and the civilians living nearby. In this regard, some best practices can also be implemented outside the storage site. It is in fact recommended to regularly trim of plants and trees around such storage sites.

Each storage unit should be marked with a symbol, according to the risk classification of United Nations labelling, which previews nine classes of risk. A Standard Operating Procedures manual should contain all the operational procedures regarding the security and the reduction of each single potential risk inside the storage unit. A very important indication deals with the deterioration of ammunition and explosives. A constant activity of controlling the quality of this material is fundamental to guarantee the minimization of risk related to an explosion. Groups of compatibility of ammunition and explosives should be formed, so to improve the level of security.

Another central requisite for the minimization of risk is the NEQ (i.e., Net Quantity Explosive) for each set of ammunition. Through the NEQ, it is possible to calculate the direct distance between the ammunition storage site and civilians' dwellings. The NEQ is to be divulged publicly by the competent organism to both the media and the civil population (IDEM).

At a regional level, at least two documents have to be mentioned, both approved in 2001: the Nairobi Protocol for Prevention, Control and Reduction of Small Arms and Light Weapons in the Great Lake Regions and the Horn of Africa, and the Protocol on the Control of Firearms, Ammunition and Other Related Materials in the Southern Africa Development Community (SADC) Region (the last one was ratified by Mozambique in 2002 and that came into effect in 2004). In this protocol, one of the most important requirements is the commitment to destroy the entire stockpile of obsolete and redundant weapons.

Starting from these principles, information and involvement of local community represents the best practice to guarantee accountability. In Africa, some experiences have been realized. In Kenya, for example, a community-driven approach to small and light weapons has been implemented with the help of the Britannic organization Saferworld. One of the central points is the operationalization of a monitoring system in local police stations to improve arms accountability, within a more general perspective directed to the building of confidence in the

PROBLEMS

OF MANAGEMENT

IN THE $21^{\text {st }}$ CENTURY

Vol. 12, No. 2, 2017 
PROBLEMS

OF MANAGEMENT

IN THE $21^{\text {st }}$ CENTURY Vol. 12 , No. 2, 2017

98

. In South Sudan a process a global contention and control of arms and arms depots has been implemented in partnership with local government, with community-level campaigns of information in Warrap State (Safeworld, 2015). In Mauritania, a NATO program leaded by Italy with a total amount of 2,25 million Euros has been implemented in 2014, in order to build two new arms depots, according to international safety and security standards (Nato, 2014).

In Mozambique, as presented in the next point, the situation is completely different, since local authorities continue to consider arms depots - as many other public goods - as "their affair", managing them with a very high level of confidentiality and a very low level of information.

\section{Risk Management in Mozambique: A General Overview}

In Africa, with the partial exception of Tanzania, all the countries in which explosions of ammunition storages occurred have been characterized by political and military instability. The Democratic Republic of Congo, Mozambique, Sudan, Nigeria, confirm this pattern. Especially after the end of the Cold War, when countries belonging to Warsaw Pact lost control of those African arms depots they had supplied, significant amounts of arms went out these storages, aiding local wars, terrorism and common delinquency. The low level of risk management inside warehouses in Africa was due only in part to technical reasons. In fact, the low level of risk management was due to an intentional choice by military (and political) bodies to have freedom to trade in the market for these arms (Gramizzi, 2014).

This scenario usually led local authorities to refrain from publicly sharing any kind of information or not engage in risk communication involving arms and arms depots activities. This is especially true when one looks at explosions of warehouses, before, during, and after the accident. Only in the most serious cases of explosions with a high number of fatalities (such as at the Malhazine warehouse in Mozambique in 2007) government is forced to do something. Generally, it means the adoption of measures to attribute individual responsibilities (to representatives of political or military bodies), but these mechanisms rarely led to understand the specific reasons and culprits for the occurrence of such tragic facts.

This mechanism not only hinders knowledge, but also makes it impossible to learn "best practices" based on previous mistakes. In fact, the audit is usually considered top secret information. In this way, the risk reduction is difficult, since the managing structure is generally trying to make up formal justifications and avoiding deep analysis of the facts that occurred.

Mozambique is a very good example of this approach employed to manage military risk. This kind of risk management should be considered as a more general idea of how risk is managed in political contexts characterized by lack of communication, information and of locals' involvement.

Cultural and historical reasons are the explanations for such approach: after having obtained its independence in 1975, Mozambique adopted a Marxist-Leninist system managed by Frelimo, a one-State party. A culture of suspicious was vastly widespread all over the country and dissent was eliminated, often in violent forms (Seibert, 2003; Meneses, 2015); a consistent movement of opposition - called Renamo, supported by Rhodesia, South Africa and USA started a civil war which ended only in 1992, with a General Pace Agreement signed in Rome. Mozambique has been considered for a long time as one of the best cases of peace process and democratization in Africa.

Nonetheless, Mozambican democracy has never been inclusive, as its position in international rankings regarding freedom shows, classifying this country as "partly free" (Freedom House, 2017). Renamo never recognized electoral results, due to claims of serious frauds in each general election that was held (Cip/Awepa, 2014). Despite explicit recommendations as set in the General Peace Agreement, Renamo never completely dismissed its military loyalist base, so that Renamo has always been considered not only as the main political party of opposition in Mozambique, but also as a military force with an army parallel 
to the governmental one. This situation contributed to shape an "ambiguous democracy", constantly at crossroads between the implementation of a democratic model and a military solution of this endless conflict.

Since the beginning of his government (2004), the idea supported by President Armando Guebuza - in charge until 2014 - was a "final solution" for Renamo and his leader, Dhlakama (Macamo, 2014). Therefore, the recurrence of the civil war in 2013 was the natural consequence of Guebuza's new strategy.

The state of emergency was never declared, but this new season of civil war, albeit circumscribed in some areas, resulted in the treatment of all issues of political and military type as highly confidential. The control by the government on public opinion was incremented, as the management of various risks can easily demonstrate. Environmental risks have been managed through an approach of strict confidentiality, as the case of Mozal bypass shows (Bussotti, $2014 \mathrm{~b}$ ), or ignoring the legitimate expectations of people forced to resettle as in the case of a coal mine in the Tete Province (Brazil). (Andrade e Sousa, 2016); Traditionally, social risk has been faced through a military response, provoking about 15 deaths during the demonstrations that occurred in 2008 and 2010, and deciding to force the local telephone operators to register all their customers in about three months, in order to have the state control the entire telephone traffic (Brito et al., 2015); political risk, represented, in the general elections of 2009, by a new party, the Democratic Movement of Mozambique (MDM), was managed excluding it in 9 out of 13 constituencies, purporting formal reasons (UE, 2009).

\section{The Management of Risk in Arms Depots in Mozambique: The Case of Malhazine's Warehouse}

In Mozambique, the management of military risk represented by arms depots followed the same principles of political risk management seen above: confidentiality, a top secret approach, reason of state and lack of information. This tendency has been accentuated once Guebuza decided to undertake a new, aggressive strategy towards Renamo, whose response was the recourse to arms.

Guebuza gave a considerable importance to Mozambican army: this element is visible not only by analysing his general politics, but also by looking at the State budget, in which military expenses constantly increased throughout the years, until the explosion of the worst financial scandal in Africa in the last few years, with more than 2 billion dollars of public secret debt contracted for strengthening the defence of Mozambican coasts and sea (Kroll, 2017).

This new atmosphere of tension and, in the end, of war, has been used as a formal reason to cover under the "top secret" strategy every kind of information regarding the management of arms depots all over the country. In addition, the poor understanding regarding the concept of "public good" led to a sort of "informal privatization" of State-owned assets (houses, cars, other kind of material, etc.) by the ruling classes, associated to a very poor request of accountability by the public opinion and mass-media (Souza, 2013); this tendency is yet more accentuated within military environments, so that no one is worried to share with the public, information on what really happens inside arms depots, how these storages are managed and what kind of damages they can provoke. And all this happens, despite the fact that many ammunition depots in Mozambique are localized nearby very populated inhabited centres.

This incommunicability represents a sort of licence to manage arms storages as if they were a private matter among military bodies. If no independent or international entity can monitor what happens at those sites, that means that every kind of activities can be carried out.

Despite the assurances that Mozambique had formally adopted international standard procedures to manage its stockpiles of obsolete ammunition and explosives, this country does not have any kind of computerized recording system and the level of risk information towards civilians living near a military command is very low, if not inexistent.

In the same fashion, the amount of information shared with the local population (i.e., the 
PROBLEMS

OF MANAGEMENT

IN THE $21^{\text {st }}$ CENTURY Vol. 12, No. 2, 2017

100

risk communication level) is very low. Between 1995 and 2007, Mozambique experienced five explosions in ammunition warehouses, with more than 115 fatalities and more than 464 injured. The most salient fact is that four out of the five explosions occurred at the same site: Malhazine, which lies right at the outskirts of Maputo (Seesac, 2007). The other explosion took place at the warehouse of Beira and, fortunately, no death occurred in that incident. Nevertheless, explosions continue also after the terrible accident of Malhazine. On January 29, 2017, the ammunition and weapon warehouse in Nacala (a city in Northern Mozambique) exploded. Furthermore, in 2012 Tito Risco, a local, died while trying to open at home a war device he had stolen from a military warehouse. Such device contained mercury and he was trying to extract the material in order to re-sell it. (Redaction, 2012).

Before this situation, some paramount questions arise naturally. How did the Mozambican Government manage these highly risky storage sites that contain war material? And what kind of risk communication did the Government implement in order to prevent destruction hitting innocent civilians?

The causes of accidents in military warehouse are generally the following: 1) Unknown $(33 \%)$. This is largely because military authorities consider the information relative to these occurrences top secret. Therefore, rarely the public receives credible explanation whatsoever. In order to avoid leaks, the information is also destroyed shortly after the occurrence, therefore precious evidence is forever lost. 2) Among the known causes, specialists indicate fire (19.6\%), movements/handling (13.7\%), security/sabotage (14.4\%), auto-ignition of propellant $(5.2 \%)$, lightning strike (5.2\%), electrical (3.3\%), other (5.2\%) (Seesac, 2007).

The strictly confidential approach that military and governmental authorities take "can lead to a reluctance to allocate responsibility" (Wilkinson, 2008: 132). However, a clear identification of the causes of these explosions could lead to a better management and reduction of risk, saving human lives. In particular, the causes of fire are largely unknown. In the case of explosion of a Nigerian military warehouse in 2002, the cause was external fires resulting in explosion (Idem: 132). In many other cases it is impossible to establish the leading cause, even if inappropriate activity related to storage and auto-ignition of propellant seem the main reasons. Despite few information available, it is possible to conclude that risk of undesirable explosions can be reduced by intensifying personnel training, by improving storage techniques, and by correctly identifying which stockpile should be considered a priority for destruction (Idem).

In Mozambique there are 17 weapons warehouses (now 16, since the Malhazine storage site was closed and now it has been transforming in a natural park), whose security level is not known, but whose management is probably below international and regional standards.

The case of explosions in Malhazine warehouse is not new. In 1985 the same military storage site exploded, provoking 13 fatalities. In 2002 the arms depot in Beira also exploded, and in March 2007 a tragedy struck again and was one of the most serious of the history of this kind of events worldwide. Local authorities considered this case as a top-secret event. Thus, information was scanty, unclear, and the tasks of attribution of responsibilities were not carried out. As everybody needed a scapegoat, one was found in the Minister of Defence, Tomás Dai. This General, the former President Guebuza's father-in-law, resigned one year after the explosion of the Malhazine depot, amid constant pressure by the local media.

Technically, the explosion at the Malhazine warehouse was due to about 20 tons of obsolete military weapons, resulting in more than 100 deaths, about 500 injured and the destruction of 12,000 homes. These precarious houses had been built nearby Malhazine depot, without respecting international standards regarding security.

In order to assess the causes of the disaster, the Mozambican Government entrusted three judges: António Pale, President of the Administrative Court and chief of the Commission, Augusto Paulino, President of the Court of Maputo, and Maria Benvida Levi, Director of the Centre of Juridical and Judiciary Formation, in order. 
As it usually happens, Mozambican authorities did not divulgate the report elaborated by the three judges, but instead, they held a press conference to provide the public with the conclusions. The Commission confirmed that the explosion at Malhazine arms depot was due to high temperatures. However, Joseph Hanlon, quoting some conclusions of this report, stated that the three experts had observed that "the munitions which exploded were stored in a building with no roof, and so were exposed to sun, rain, heat and cold". In addition, "the military was failing to observe the appropriate procedures for storing munitions and that there were "manifest irregularities" in the inspection of the shells", but the commission excluded actions of sabotage or attempts to extract mercury from the shells (Hanlon, 2007a).

Many observers and politicians belonging to Renamo contested this conclusion: in his speech to the Mozambican Parliament, Eduardo Namburete expressed concerns regarding the Government's position, observing that Malhazine depot posed yet a very real risk for civilians (Namburete, 2007). A Mozambican blogger, Komba Kanema, considered the justification given by government as not credible, adding that the most surprisingly new - communicated by the Minister of Defence, Tomás Dai - was that war device in Malhazine was stored outdoors, without much concern or care (Komba Kanema, 2007).

As a report commissioned by the South-African Strategic Studies Institute after the explosion of Malhazine depot pointed out, Mozambique did not respect its commitment to eliminate obsolete arms, according to the above mentioned Protocol of SADC, ratified by Mozambique in 2002. In addition, this report accused openly Mozambican authorities to be directly responsible for the disaster: a series of questions and accusations were launched in the South-African report. Why were civilian dwellings built nearby the arms depot? Why Mozambique did not yet destroy all its obsolete arms? Why local authorities did not move the depot far away from such a densely populated site? And, finally, the report refutes the official version given by Mozambican Government, pointing out that high temperatures rarely can cause the tragic events occurred at Malhazine, concluding that it was a human error that caused the explosion (Stott, 2007).

As a matter of fact, thus far, nobody has been able to establish conclusively what caused the explosion of Malhazine armour, due to the extremely confidential approach adopted by local authorities, as Banjo also purports (Banjo, 2010).

SEESAC, together with UNDP, produced another independent report on the causes of this tragedy. The author was Adrian Wilkinson and the conclusions were similar to those reached by ISS. Once more, it is Joseph Hanlon who summarizes the results reached in the SEESAC report, as following: "Deterioration of the Physical or Chemical Condition of the Ammunition or Explosives", in particular "Autocatalytic decomposition of propellant leading to spontaneous ignition." (Hanlon, 2007b).

Nevertheless, the most important element for the issue here approached - risk management and risk communication - is the declaration of Hanlon about the SEESAC report on Malhazine: "Adrian Wilkinson has requested that I remove that full report from the website because "institutional relationships between UNDP and the Govt of Mozambique may be negatively impacted if the whole document is left in the public forum". I personally believe that the report should remain public, to avoid errors and misquotations. Nonetheless, I have acceded to Mr Wilkinson's request" (Idem).

The Mozambican sociologist, Carlos Serra, which manages one of the best-known websites in the Lusophone Africa, "Diário de um sociólogo" (oficinadesociologia.blogspot. com) posted the whole report issued by SEESAC. However, the actual report is no longer available. It means that the report has been removed as a form of censorship, as it already happened in the case of Joseph Hanlon.

Without carrying out a serious inquiry aimed at understanding the real causes of the tragedy and the people responsible for it, the Mozambican government preferred to constitute a Cabinet for the Support of the Victims of the Warehouse of Malhazine, headed by Cristina Matavel, whose main task was to rebuild the houses destroyed by the explosion. Carlos Tembe,

PROBLEMS

OF MANAGEMENT

IN THE $21^{\text {st }}$ CENTURY

Vol. 12, No. 2, 2017 
PROBLEMS

OF MANAGEMENT

IN THE $21^{\text {st }}$ CENTURY Vol. 12 , No. 2, 2017

102

at that time city councillor in Maputo for the independent list "Juntos pela Cidade" denounced the very poor conditions of the new houses, built without following basic guidelines and in an environment characterized by corruption. In addition, he pointed out that five months after the tragic event, the Forum of citizens, which had been constituted to support the victims of Malhazine and their families had not played any meaningful role (Casas das vítimas, 2007).

In addition to the enormous suffering stemming from the loss of their loved ones, many families did not have the legal right to be supported financially or compensated for the damages. The case of the couple composed by Rodrigues Mafuiane and Marcelina Langa is emblematic on how Mozambican authorities dealt with this situation. The couple lost two children in the explosion of the arms depot of Malhazine. Nonetheless, the local cabinet of Social Affairs informed them that the help would be limited for the burial's expenses of their two children. Because, as minors, they received their subsistence by their parents, Mr. Rodrigues and his wife did not receive any other kind of financial help or indemnity (MMT, 2011).

\section{Final Remarks}

Risk management and risk communication represent, today, basic instruments to prevent and diminish tragedies caused by man-made activities, such as those originated by explosions in military armour.

This study showed that it is possible to highlight some political and cultural characteristics that induce local authorities to maintain their strict confidentiality in the management of arms and ammunition depots. Mozambique is probably paradigmatic in this sense: as a "partially free" country, it has experienced a prolonged civil war and the approach inspiring local authorities regarding institutional issues, yet more when concerning with military issues, continues to be characterized by "high confidentiality". Thus, local authorities did not prevent the accident and did not perform, in practice, any type of investigation, preferring instead to constitute, one month after the explosion, a Cabinet of Social Support to sustain the victims of the Malhazine accident, whose work left much to be desired. Scanty information circulated in this regard as well, although Estêvão João is probably correct when he writes that there is not much knowledge about a substantial number of people affected by the explosion filing claims probably because these people were refused compensation by the Government (JOÂO, 2015).

On the other hand, the Mozambican Government moved all the obsolete arms and ammunition that were still stored at the Malhazine depot far away the city of Maputo, while the military storage site of Malhazine has been transformed (as set in a 2012 Decree) in a Natural Park. Thus, the risk was physically removed, the area will be transformed in an ecological statement, but at least three great questions continue to be unresolved.

Firstly, the lack of information by the Mozambican Government did not help local authorities to learn new, "good practices". Military structures will continue to manage obsolete arms and ammunition depots countrywide as they have been used to do till now, with a high risk of uncontrolled explosions. The last accident into the armoury of Nacala in 2012 confirms it. Military risk stemming from unfit storage and handling did not decrease after the Malhazine tragedy.

Secondly, to avoid other accidents, it is impossible to remove all other arms and ammunitions depots present all over the country. Mozambican authorities never formulated such hypothesis; nonetheless, a serious process of risk assessment of these military structures, especially those nearby populated centres, should be carried out. And this assessment should involve professionals, such as urbanists, architects and so on.

Finally, the strategy of avoiding inquiries which could be used against public and military officials, in favour of very uncertain mechanisms of financial compensation for the victims and their families, does not appear the best way to prevent episodes as those of Malhazine: if nobody is responsible, thus it means that nobody should be held accountable for the death of more than 100 people. A good risk management should contain also procedures directed to identify tasks, responsibilities and, when necessary, culprits. 
The political and military tension which Mozambique is living has represented the main justification to induce local authorities to maintain a strict confidentiality on issues related to arms and ammunition depots. According to this logic, Renamo, the old enemy, cannot know the potential of arms and ammunition stored in Mozambican warehouses: so, all this delicate issue is managed as if it were a private question of political and military elite, leaving Mozambican society to the dark.

So, historical, cultural and political reasons are converging because in Mozambique very dangerous structures, like warehouses, continue to be managed according to principles contrary to the current theories of risk and communication management and to the basic principle of accountability of public structures.

\section{References}

Andrade e Sousa, M. E. de (2016). A exploração mineira e o reassentamento forçado em Moçambique: uma reflexão sobre a situação dos deslocados do desenvolvimento. Revista Interdisciplinar da Mobilidade Humana, A. XXIV, 27, 204-209.

Banjo, A. (2010). Reflections on the military armoury disaster in Mozambique, March 2007. Journal of Military and Strategic Studies, 12 (2), 2-19.

Beck, U. (1986). Risikogesellschaft: Auf dem Weg in eine andere Moderne [Risk society: On the way to another modernity]. Frankfurt am Main: Suhrkamp.

Beck, U., Giddens, A., \& Lash, S. (Eds.) (1994). Reflexive modernization: Politics, tradition and aesthetics in the modern social order. Standford: Standford University Press.

Brito, L. de et al. (2015). Revoltas da Fome: Protestos Populares em Moçambique (2008-2012). Cadernos IESE N. 14P. Maputo: IESE.

Bussotti, L. (2014a). The risk of current political risk management. Problems of Management in the $21^{\text {st }}$ Century, 9 (3), 170-172.

Bussotti, L. (2014b). Environmental risk management and communication in an African context: The case of the Mozal bypass in Mozambique. Cadernos de Estudos Africanos, 28, 93-118.

Bussotti, L. (2015). A gestão do "risco político" na democracia moçambicana: análise e prespectivas [The management of "political risk" in Mozambican democracy: Analysis and perspectives]. Estudos de Sociologia, 2 (20).

Casas das Vítimas do Paiol de Malhazine (2007). Canal de Moçambique. Retrieved from http:// mozmiradouronline.blogspot.com/2007/08/casas-das-vtimas-do-paiol-de-malhazine.html.

Cip/Awepa (2014). Frelimo wins another tainted election. Mozambican political process bulletin, Issue 56, 28/11/2014. Retrieved from https://www.open.ac.uk/technology/mozambique/sites/www.open. ac.uk.technology.mozambique/files/files/Mozambique_Bulletin_56_Election_results_2014(1). pdf.

Covello, V. T. (1983). The perception of technological risks: A literature review. Technological Forecasting and Social Change, 23, 285-297.

Dahl, R. (1957). The concept of power. System Research and Behavioral Sciences, 2 (3), 201-215. DOI: $10.1002 /$ bs.3830020303.

Douglas, M. (1992). Risk and blame: Essays in cultural theory. London \& New York: Routledge.

Freedom House (2017). Freedom in the World 2017 - Mozambique profile. Retrieved from https:// freedomhouse.org/report/freedom-world/2017/mozambique.

Giddens, A. (1990). The consequences of modernity. Cambridge: Polity.

Gramizzi, C. (2014). Tackling illicit small arms and light weapons (SALW) and ammunition in the Great Lakes and Horn of Africa. Africa Peace Forum - China Arms Control and Disarmament Association - Saferworld. Retrieved from http://www.saferworld.org.uk/resources/viewresource/838-tackling-illicit-small-arms-and-light-weapons-and-ammunition-in-the-great-lakesand-the-horn-of-africa.

Hanlon, J. (2007a). Armoury explosion: 105 dead 1300 houses hit "Manifest Irregularities". News reports \& Clippings, 114.

Hanlon, J. (2007b). Report on the SEESAC/UNDP 'Quick Look' at the Malhazine armoury explosion of 22 March 2007. Retrieved from https://www.open.ac.uk/technology/.../sites/.../d74936.doc.

João, E. (2015). Afinal, o que é feito do paiol de Malhazine? [After all, what is made of the Malhazine?] Notícias, 08/08/2015. 
Luca BUSSOTTI. Risk management and risk communication in Mozambique: The case of arms and ammunition depots of Malhazine

PROBLEMS

OF MANAGEMENT

IN THE $21^{\text {st }}$ CENTURY Vol. 12, No. 2, 2017

104

Kalberg, S. (1980). Max Weber's type of rationality: Cornerstones for the analysis of rationale processes in history. The American Journal of Sociology, 85 (5), 1145-1179.

Kasperson, R. et al. (1988). The social amplification of risk: A conceptual framework. Risk Analysis, 177-187.

Komba Kanema (2007). Guerra contra o povo [War against the people], 23/03/2007. Retrieved from http://ideiasdebate.blogspot.it/2007/03/guerra-contra-o-povo.html.

Kroll (2017). Independent audit related to loans contracted by ProIndicus S.A, Ematum S.A. and Mozambique Asset Management S.A. Maputo: Kroll.

Luhmann, N. (1979). Trust and power. Chichester: John Wiley.

Lupton, D. (1999). Risk. London: Rutledge.

Macamo, E. (2014). Cultura política e cidadania em Moçambique: uma relação conflituosa [Political culture and citizenship in Mozambique: A conflicting relationship]. In Brito, L. de, Castel-Branco, C.N., Chichava, S. \& Francisco, A. (Eds.). Desafios para Moçambique 2014. Maputo: IESE, pp. 41-60.

Meneses, M. P. (2015). Xiconhoca, o inimigo: Narrativas de violência sobre a construção da nação em Moçambique [Xiconhoca, the enemy: Narratives of violence on the construction of the nation in Mozambique]. Revista Crítica de Ciências Sociais, 106, 9-52.

MMT (2011). Ester, um rosto visível das explosões do paiol em Maputo [Ester, a visible face of the explosions of the loom in Maputo]. Agência Lusa. Retrieved from http://noticias.sapo.mz/lusa/ artigo/12321961.html.

Namburete, E. (2007). A Hipocrisia do Poder e a Morte dos Pobres [The hypocrisy of power and the death of the poor]. Retrieved from http://namburete.awardspace.com/discursos.php?subaction=sh owfull\&id $=1225661961$ \&archive $=\&$ start from $=$ \&ucat $=36 \&$.

NATO - NATO SUPPORT AGENCY (2014). Mauritania. Available at www.nspa.nato.int, accessed $07 / 07 / 2017$.

Purcell, E. (2016). Capitalism and risk: Concepts, consequences and ideologies. Buff L. Review 64, pp. 23-59. Retrieved from http://digitalcommons.nyls.edu/cgi/viewcontent. cgi? article $=1432 \&$ context $=$ fac_articles_chapters

Redaction (2012). Artefacto de guerra roubado num paiol mata jovem na Beira [Artifacts of war robbed in a pearl kills young in Beira]. O Pais, 12/01/2012.

Safeworld (2012). Stockpile management of weapons and weapons safety. In http://www.saferworld.org. uk.

Safeworld (2015). Effective SALW control in Kenya: Community-driven approach. Retrieved from http://www.saferworld.org.uk/resources/view-resource/877-effective-salw-control-in-kenyacommunity-driven-approaches.

Seesac (2007). Recent explosive events in ammunition storage areas, Vol. 5, Belgrade: Seesac.

Seibert, G. (2003). The vagaries of violence and power in post-colonial Mozambique. In Abbink, J., Bruijn, M. E. de \& Walraven, K.Van (Eds). Rethinking resistance: revolt and violence in African history. Leiden: Brill, pp. 254-276.

Sinisi, L. (2004). Public concerns and risk communication. Rome: National Environmental Protection Agency.

Sjöberg, L., Moen, B.-E., \& Rundmo, T. (2004). Explaining risk perception. Trondheim: Rotunde.

Slovic, P. (1987). Perception of risk. Science, 236, 280-285.

Slovic, P. (1993). Perceived risk, trust, and democracy. Risk Analysis, 13, 675-682.

Sousa Santos, B. de (2004). Do pós-moderno ao pós-colonial. E para além de um e outro [From the postmodern to the postcolonial. And apart from each other]. Retrieved from http://www.ces.uc.pt/ misc/Do_pos-moderno_ao_pos-colonial.pdf

Souza, J. G. de (2013). A Questão Indígena: Acumulação por Espoliação e Monopolização do Território (A Economia Política do Agronegócio) [The indigenous question: Accumulation for spoliation and monopolization of the territory (The political economy of agribusiness)]. Prima Facie, 12 (22), 1-42.

Sowby, F. D. (1965). Radiation and other risks. Health Physics, 11 (9), 879-887.

Starr, C. (1969). Social benefit versus technological risk. Science, 165 (3899), 1232-1238.

Stott, N. (2007). Mozambique Arms explosion exposes more than poor stockpile management. South Africa: Institute for Security Studies. Retrieved from https://oldsite.issafrica.org/iss-today/ mozambique-arms-explosion-exposes-more-than-poor-stockpile-management. 
UE (União Europeia - Missão de Observação Eleitoral) (2009). Relatório final - Moçambique 2009. OF MANAGEMENT
IN THE 21 $1^{\text {st }}$ CENTURY
Vol. 12, No. 2, 2017 Maputo: UE

U.S. Department of State's Bureau of Political-Military Affairs (2010). Dangerous Depots: The Growing Humanitarian Problem Posed by Aging and Poorly Maintained Munitions Storage Sites. Washington: U.S. Department of State.

Wilkinson, A. (2008). Ammunition depot explosion. In Bevan, J. (Ed.). Conventional Ammunition in Surplus, Geneve: Small Arms Survey, pp. 129-135.

Received: October 02, 2017

Accepted: December 15, 2017

Luca Bussotti

$\mathrm{PhD}$, Researcher at the International Studies Center, ISCTE-IUL, Lisbon, Avenida das Forças Armadas, Lisboa, Portugal.

E-mail: Luca.Bussotti@iscte-iul.pt 